\title{
"Something Unspeakable": James Baldwin and the "Closeted-ness" of American Power
}

\author{
David C. Jones Edge Hill University
}

\begin{abstract}
This article reads the work of James Baldwin in dialogue with that of Eve Kosofsky Sedgwick. Taking its cue from Baldwin's claim that Americans "live [...] with something in [their] closet" that they "pretend [...] is not there," it explores his depiction of a United States characterized by the "closeted-ness" of its racial discourse. In doing so, the article draws on Sedgwick's work concerning how the containment of discourses pertaining to sexuality hinges on the closeting of non-heteronormative sexual practices. Reconceptualizing Sedgwick's ideas in the context of a black, queer writer like Baldwin, however, problematizes her own insistence on the "historical gay specificity" of the epistemology she traces. To this end, this article does not simply posit a racial counterpart to the homosexual closet. Rather, reflecting Baldwin's insistence that "the sexual question and the racial question have always been entwined," I highlight here the interpretive possibilities opened up by intersectional analyses that view race, sexuality, and national identity as coextensive, reciprocal epistemologies.
\end{abstract}

Keywords: James Baldwin, Eve Kosofsky Sedgwick, closet, closeted, Black Queer Studies, African-American literature, Queer Theory

In September 1963, James Baldwin appeared on American radio alongside Malcolm X. Tasked with assessing the efficacy of the contemporary "sit-in" movement, Baldwin shifts the conversation to what he perceives as the imperative to "re-examine the basis" on which American race relations are predicated. ${ }^{1}$ Where Malcolm cautions against the movement making racial integration its primary goal, Baldwin counters that integration is a "false issue," given the preponderance of already existing biracial people in the United States. ${ }^{2} \mathrm{He}$ insists instead that it is the "standards of this country," standards that fail to acknowledge this integrated

James Baldwin Review, Volume 3, 2017 (c) The Authors. Published by Manchester University Press and The University of Manchester Library 
heritage, that must be addressed if racial equality is to be achieved. ${ }^{3}$ "No one in this country," Baldwin asserts,

really knows any longer what it means to be an American. He does not know what he means by freedom. He does not know what he means by equality. We live in the most abysmal ignorance of not only the condition of the 20 million Negroes in our midst, but of the whole nature of the life being lived in the rest of the world [...] You cannot live $[\ldots]$ with something in your closet, which you know is there and pretend it is not there without something terrible happening to you. ${ }^{4}$

The overriding effect of such "standards," he continues, is a culture upon which "absolute silence" descends. ${ }^{5}$

Baldwin's comments concerning the "abysmal ignorance" and "absolute silence" at the heart of American culture rehearse a key theme in his writing. ${ }^{6}$ Throughout his oeuvre, he evokes an America-or, more accurately, a white America-whose power hinges on concealing difficult truths concerning its history of racial and sexual oppression. In his seminal 1963 essay, The Fire Next Time, for instance, he declares: "it does indeed mean something-something unspeakable-to be born in a white country, an Anglo-Teutonic, antisexual country, black." " Elsewhere, he refers to the presence of African Americans in the United States as eliciting "the tension of a silence filled with things unutterable." 8 Racially motivated lynching, meanwhile, is characterized by him as the manifestation of "unspeakable longings." In a similar vein-and recapitulating Oscar Wilde's famous allusion to a love that "dare not speak its name"-same-sex desire is described by Baldwin as "something unspoken [...] something unspeakable, undone and hideously desired." 10 In each case, the parameters of American discourse are positioned as being heavily circumscribed, with non-white, non-heteronormative people excluded from the representational domain in which American identity is conceived and articulated. It is this culture that Baldwin gestures toward in his invocation of an America that lives with "something in [its] closet."11

The notion of there being a "closet" structuring Baldwin's vision of American history and culture provides the backdrop to this essay. Specifically, I propose that the American "standards" he condemns may be further elucidated by reading them in conjunction with ideas developed by Eve Kosofsky Sedgwick in Epistemology of the Closet (1990). Sedgwick's analysis famously traces the history and related knowledge and power associated with the homosexual closet, an instrumentality she characterizes as the "defining structure for gay oppression in the twentieth century." 12 While at the most basic level the closet names the cultural imperative for non-heteronormative people to conceal their sexuality, it also acts as the vehicle through which heterosexuality is naturalized. The closet simultaneously forecloses that which threatens to violate heterosexual privilege and reaffirms this privilege through the same process of exclusion. In doing so, the closet sets the parameters of normative discourse. The existence of a defiled homosexuality at its threshold orients heterosexuality, mapping the representational terrain on which sexual identity may legitimately be constructed. 
When Baldwin deploys the closet metaphor in conversation with Malcolm X, it is clearly not this specific epistemology that he is speaking of. There is nothing to suggest that his comment is some kind of knowing allusion to the cultural norms and attendant discourse that circumscribe queer sexuality. He does, however, deploy the image of a closet in the context of same-sex relations in his 1956 novel Giovanni's Room. The novel's depiction of a homosexual affair between an American expatriate and an Italian bartender in Paris largely plays out within what the former describes as a "miserable closet of a room." ${ }^{13}$ However, rather than focusing on explicit usages of the closet metaphor in Baldwin's work, my interest here is in how the "closeted-ness" Sedgwick associates with homosexuality is mirrored in Baldwin's depiction of American race relations. ${ }^{14}$ Echoing Phillip Auger, I define closeted-ness as "a state in which discourse is contained." 15 In doing so, I propose that significant theoretical parallels can be drawn between Baldwin's work and Sedgwick's ideas. First, Baldwin's excavation of the hidden recesses of American history and culture identifies the consolidation of power with an asymmetrical identity binarism. In this regard, his work echoes Sedgwick's excavation of the power relations underpinning heteronormativity. According to Sedgwick, an "ontologically valorized" heterosexual dyad derives its meaning from the "simultaneous subsumption and exclusion" of its "subordinated" homosexual other. ${ }^{16}$ In Baldwin's case, however, the dyad is racialized, with blackness, in effect, supplanting homosexuality as the excluded dyad. Secondly, Sedgwick's emphasis on the constitutive role ignorance plays in closeted-ness is echoed in Baldwin's analysis of race. Her argument that the closet's epistemology sees ignorance "collude or compete with knowledge," rendering silence "as pointed and performative as speech," mirrors Baldwin's frequent references to blackness as "unspeakable" and the "innocence" of white Americans concerning the plight of African Americans. ${ }^{17}$

Baldwin's work, therefore, may be understood as a racial counterpart to some of Sedgwick's key ideas about sexualities. The existence of a racial closet, however, means pushing against the conceptual limits of Sedgwick's own closet paradigm. Cautioning against what she perceives as the closet's potential for "floating free from its gay origins," she maintains that sex and hegemonic power are "conceptually inseparable" from one another. ${ }^{18}$ As such, denying the "historical gay specificity" of the epistemology she traces risks, in Sedgwick's view, re-inscribing the very power relations that the closet is a vehicle for. ${ }^{19}$ To minimize the closet's gay specificity, she argues, is to erase the extent to which "a whole cluster of the most crucial sites for contestation of meaning in twentieth century Western culture" have been saturated with "the suffusing stain of homo/heterosexual crisis." ${ }^{20}$ Among the sites for contestation that Sedgwick identifies are "private/public," "masculine/ feminine," and "majority/minority." ${ }^{21}$ Critically, however, "black/white" is absent from her list. Reading Sedgwick through the work of a black, queer writer like Baldwin problematizes this absence considerably. In Baldwin's work, epistemologies of race, sexuality, and, indeed, the United States are as "conceptually inseparable" from one another as they are from the practice of power. Accordingly, I 
seek to interpret Sedgwick through Baldwin as well as vice versa. In doing so, I propose that Baldwin's emphasis on the "vast sexual implications of our racial heritage" demonstrates the imperative of what Marlon B. Ross characterizes as the necessity to move beyond the idea of the closet as a "raceless paradigm." 22 Doing so necessarily involves expanding the interpretive scope of Sedgwick's paradigm to reflect the fact that all power hinges on some degree of closeted-ness.

The post-war period in which Baldwin came to prominence offers a particularly potent example of the relationship between closeted-ness and hegemonic power. The collusion between ignorance and knowledge identified by Sedgwick did much to shape the ideological contours of 1950s America. Indeed, as Alan Nadel argues, there are a number of structural similarities between the narrative of "containment" that pervaded early Cold War America and Sedgwick's ideas. Like the closet, the bifurcation of "American" versus "un-American" mobilized by Cold War containment foregrounded the imperative of what Nadel terms "clear, legible boundaries between Other and Same," which inscribed "a matrix of binary oppositions," the relative value of which were determined by "a weighted set of social norms." 23 Just as the closet constructs heterosexual identity through a defiled homosexual other, so the American Cold War, with its institutionalization of "un-American activities" in the form of the House Un-American Activities Committee and McCarthyism, constructed a model of national identity that derived its meaning from its disavowed other. ${ }^{24}$ Moreover, the so-called "lavender scare," which saw hundreds of suspected homosexuals losing federal jobs on account of their supposed vulnerability to blackmail by Soviet agents, provides a clear example of Sedgwick's claim that "the suffusing stain of homo/heterosexual crisis" underwrote twentieth-century cultural norms in Europe and the United States. ${ }^{25}$ The episteme of containment-era America, therefore, may be understood as corresponding to the epistemology of the closet.

It was within and against this historical framework that Baldwin's work was pitched. The America he depicts in his writing is a nation predicated on the kind of "clear, legible boundaries between Other and Same" referred to by Nadel. ${ }^{26}$ It is a culture whose standards are the product of binary thinking. "The American vision of the world," he writes in "Stranger in the Village" (1953), "tends until today to paint moral issues in glaring black and white." 27 This morality, he adds, "owes a great deal to the battle waged by Americans to maintain between themselves and black men a human separation" that cannot be bridged. ${ }^{28}$ In other words, America's black and white moral vision is inextricable from its black and white racial politics. Sustaining this perspective, Baldwin suggests, depends on an impermeable racial fault line that positions "Americans" and "black men" as mutually exclusive terms.

The result of this kind of separation, however, is that the very same blackness that America's racialized vision disavows becomes, paradoxically, inseparable from it. The distinction it offers provides the discursive coordinates for a particular paradigm of American identity, one rooted in a "national self-image" that Baldwin characterizes elsewhere as "a cross between the Teuton and the Celt" 
and "which suggests hard work and good clean fun and chastity and piety." ${ }^{29}$ To bridge this separation, therefore, would necessarily involve revising what, to paraphrase the title of another of his essays, it means to be an American, so that it encompasses the historical experiences of the nation's black inhabitants. Doing so would, in turn, fatally compromise the clear-cut morality that Baldwin identifies as the basis of the "American vision of the world."

Baldwin's emphasis on the separation of black and white Americans sees him rehearsing the binary thinking that characterized the American Cold War. As Mary Dudziak and Reynold Humphries have demonstrated, the epithet "un-American" was frequently deployed by segregationists, while advocates of integration were accused, in some quarters, of spreading a "communistic disease." 31 To suggest that integration is un-American presupposes the un-American-ness of blackness, foregrounding the coextensive relationship between American-ness and whiteness in the American cultural imaginary. Accordingly, whether referring to morals or race, "the glaring black and white" to which Baldwin alludes names the desire of a white American "self" to distinguish and close itself off from a black "other" that at once imperils and orients the legitimacy of its power. ${ }^{32}$

The relationship between American identity and racial separation that Baldwin refers to in "Stranger in the Village" is explored further in The Fire Next Time. To be African-American, Baldwin writes, is to inhabit a "universe [that] has evolved no terms for your existence, has made no room for you." ${ }^{33} \mathrm{He}$ goes on to add that the United States' claim to be "the greatest country the world has ever seen" hinges on a "collection of myths" that extol an ancestry of "freedom loving heroes," while simultaneously keeping "the truth about the black man, as a historical entity and as a human being [...] hidden from him deliberately and cruelly." ${ }^{34}$ As in "Stranger in the Village," these statements present the shared bases of identification through which national identity is forged as hinging on a separation from, and disavowal of, the experiences of African Americans. It is precisely because the historical experiences of African Americans are "hidden" that the mythology of "freedom loving heroes" can be naturalized. Any role blackness does have in the symbolic order of the United States, Baldwin suggests, is merely as a function of whiteness, with a repudiated black otherness serving as what he describes as "the fixed star" and "immovable pillar" that orients the white world's sense of "reality." ${ }^{35}$ Containing blackness within these parameters once again assumes its un-American-ness and, in doing so, preserves "clear, legible boundaries between Other and Same." ${ }^{36}$ The African Americans' history of what Baldwin characterizes as "rope, fire, torture, castration, infanticide, rape" effectively vanishes from the American cultural imaginary, making American identity synonymous with the kind of Teutonic whiteness referred to above. ${ }^{37}$

What we see in both "Stranger in the Village" and The Fire Next Time is the logic of Sedgwick's closet transposed onto a racial context. An "ontologically valorized" American-ness, "the greatest country the world has ever seen," is contingent on the "simultaneous subsumption and exclusion" of African Americans as both historical entities and human beings. ${ }^{38}$ It is, quite simply, the closeted-ness 
of racial discourse that consolidates white hegemonic power. Moreover, a clear parallel emerges between how the respective "ontologically valorized" dyads of Baldwin and Sedgwick are naturalized. Baldwin's suggestion that white America positions blackness beyond the threshold of representation, insofar as it has "evolved no terms" for it and rendered it "unspeakable," mirrors Sedgwick's point that in homophobic discourse "silence [...] performs the enforcing work of the status quo." 39 In each case, the closeted-ness of the subordinated "other" points to a power relation that is produced and maintained through absence. Though recognizing that knowledge remains the "magnetic field of power," Sedgwick insists on the constitutive role played by ignorance and silence in the production of heteronormativity. ${ }^{40}$ "[I]n relations around the closet," she writes, "ignorance is as potent and multiple a thing [...] as is knowledge." She continues: "Far from being pieces of the originary dark," these multiple ignorances "are produced by and correspond to particular knowledges and circulate as part of particular regimes of truth."41

What Sedgwick describes here is an extension of the principle of "knowledge/ power" as developed by Michel Foucault. For Foucault, knowledge names the shared stock of ideas, values, rituals, and narratives that coalesce in particular contexts, allowing "the sovereignty of collective consciousness to emerge as the principle of unity and explanation." ${ }^{2}$ Critically, this knowledge is never ideologically neutral. "[T]here is no power relation," Foucault writes, "without the correlative constitution of a field of knowledge, nor any knowledge that does not presuppose and constitute at the same time power relations." ${ }^{43}$ Baldwin's description of an America that conceives of itself as "the greatest country the world has ever seen" on account of an ancestry of "freedom loving heroes" is illustrative of this point. ${ }^{44}$ This collective consciousness at once produces American "knowledge/power" and is produced by it. Sedgwick, however, modifies this principle to suggest a power relation that is simultaneously contingent on a correlative field of ignorance. The closet withholds and erases knowledge concerning queer sexuality from the representational domain. As such, it presupposes the principle of ignorance being constitutive of the sovereignty of heterosexuality. Silence becomes as "performative as speech," in that its repetition over time helps create the impression of continuity that naturalizes and consolidates heteronormativity. ${ }^{45}$ In this regard, the closet may be understood as mobilizing a discourse of "ignorance/power" that exists in conjunction with Foucault's conception of "knowledge/power."

Baldwin's claim that the United States has "evolved no terms" for the existence of African Americans, coupled with his frequent invocations of blackness as "unspeakable," points to a similar performative silence underpinning the closeted-ness of America's racialized epistemology. ${ }^{46}$ It is the lack of vocabulary for the experiences of African Americans that "performs the enforcing work" of what Baldwin defines as the nation's "Anglo-Teutonic" status quo. ${ }^{47}$ The "collection of myths" that supplies the United States with the knowledge for its collective consciousness is supplemented by a silence regarding the historical plight of African Americans. ${ }^{48}$ Ignorance concerning African Americans thus produces and 
corresponds to American "knowledge/power," circulating as part of its regime of truth.

The principle of ignorance being constitutive of American power is revealed most forcibly in Baldwin's writing in his analysis of what he terms "the national innocence." 49 This idea is a key leitmotif in his writing, punctuating texts including The Fire Next Time, Giovanni's Room, and Another Country (1962), and is a theme he turns to repeatedly when critiquing existing power relations in the United States. By foregrounding the theme of American innocence, Baldwin, in a sense, rehearses one of the foundational principles of America's historical identity. The idea of the United States' historical exceptionalism, its status as a "new Eden" free from the supposed corruption of the Old World, has been a staple of American cultural discourse since the country's inception. As Grace Tiffany notes, "seventeenth century English Puritan descriptions of America evoke the Eden of Genesis," with the writings of explorers and early settlers, such as John Smith, Francis Higginson, and William Bradford, depicting an unspoiled "green New World" that could provide the setting for a new, religiously pure, Christian civilization. ${ }^{50}$ Perhaps the most famous example of this idea can be found in John Winthrop's “A Model of Christian Charity” (1630), a sermon originally delivered aboard the Arabella, a ship bearing English Puritans to America. Winthrop's sermon concludes with him calling for the creation of a new society, "a city on the hill," which will serve as a model for others to emulate. ${ }^{51}$ Framing the New World as a New Eden in this way presupposed its primordial innocence. In doing so, Winthrop helped establish the vocabulary for American exceptionalism that endures to the present day.

Perhaps unsurprisingly, the notion of America's innocence was particularly pronounced during the early Cold War period in which Baldwin established his literary reputation. As H. W. Brands argues, the geopolitical exigencies of the Cold War necessitated that Americans "cling to the myth of their innocence more than ever." 52 The assumption of the a priori virtuousness of the United States provided the ideological ballast for the containment of the Soviet Union, while simultaneously allowing for the expansion of the "American moral frontier" to encompass a hastily designated "free world" amenable to free market capitalism and liberal democracy. ${ }^{53}$ More broadly, the principle of the nation's innocence functions as a key trope in the American literary imagination, evident in works ranging from those of nineteenth-century writers like Henry David Thoreau, Ralph Waldo Emerson, and Walt Whitman all the way through to contemporary superhero narratives. ${ }^{54}$ American innocence may be seen, therefore, as both constitutive of and constituted by the collective consciousness of the United States, reproduced periodically by the very field of knowledge it helped to create.

Baldwin, however, repudiates American innocence. For him, it is contingent on the erasure of America's historical crimes and, thus, reifies ignorance as the basis of the nation's prevailing hegemony. Pressed by David Leeming to explain his understanding of the term, Baldwin suggests that innocence refers to "the 'general failure'-the failure to touch, to see." 55 In other words, innocence is symptomatic 
of a failure to acknowledge the material reality of the "other" when confronted with it; it is to contain discourse by withholding entry into the representational domain where knowledge is constituted. George Shulman elucidates this idea, writing that "Baldwinian innocence" names a "dream of safety, sovereignty, or purity" that hinges on the "denial of history" and "denying the social landscape of power and our differential positioning in it." 56

"My Dungeon Shook" (1962), the letter from Baldwin to his 14-year-old nephew and namesake that provides the introduction to The Fire Next Time, provides a powerful example of what "Baldwinian innocence" means in practice. Baldwin writes: "Now, my dear namesake, these innocent and well-meaning people, your countrymen, have caused you to be born under conditions not very far removed from those described for us by Charles Dickens in the London of more than a hundred years ago." 57 Such conditions are the result of the "denial of history" and "failure to touch [and] to see" referred to by Shulman and Baldwin, respectively. ${ }^{58}$ What Baldwin defines as "the crime of which I accuse my country and my countrymen" is "that they have destroyed and are destroying hundreds of thousands of lives and do not know and do not want to know it." 59 A parallel can be drawn here with what Sedgwick identifies as the "privilege of unknowing" that the epistemology of the closet gives rise to.$^{60}$ Explicating this idea, Sedgwick uses the example of a 1986 U.S. Justice Department ruling, whereby employers were granted permission to dismiss an employee with AIDS, providing that they could demonstrate that they were ignorant of the medical fact that the disease poses no known health danger in the workplace. ${ }^{61}$ In this context, ignorance is not merely the absence of knowledge but an instrument of oppression. "Baldwinian innocence" follows a similar pattern. Not knowing and not wanting to know is symptomatic of what Lawrie Balfour characterizes as a kind of "moral insulation" on the part of white Americans. ${ }^{62}$ Their "innocence" when confronted with the kind of conditions described by Baldwin allows them to absolve themselves of responsibility, while simultaneously reaping the socio-economic privileges of a racially delineated social order that is weighted in their favor.

American innocence, then, is far from innocent. Rather, as Baldwin states, "[i]t is the innocence which constitutes the crime" to which African Americans have historically fallen victim. ${ }^{63}$ Here, once again, Baldwin's work demonstrates the closeted-ness that underwrites the racial epistemology of the United States. To acknowledge the historical claims of African Americans is to erode the very foundations on which the United States' existing social order is premised. Therefore, the ignorance and silence for which innocence is a synonym serve a vital epistemological function that corresponds to the power relations mobilized by the homosexual closet. In the same way that the closet helps ward off the potential of what Sedgwick terms a "definitional crisis" in the realm of gender and sexuality, white Americans' innocence in relation to the historical experiences of African Americans becomes a way of containing a discourse that threatens the United States' national self-image. ${ }^{64}$ If American history is one of "rope, fire, torture, castration, infanticide, rape" as opposed to "freedom loving heroes," its raison 
d'être, the claim of historical exceptionalism and primordial innocence on which the nation's identity is predicated, is fatally undermined.$^{65}$ As such, just as any blurring of the distinction between homosexuality and heterosexuality imperils what Sedgwick defines as one of the "presiding master term[s] [...] of modern Western identity," so removing the hitherto "fixed star" of racial difference precipitates a concomitant crisis of identity for white Americans ${ }^{66}$ As Baldwin puts it, "heaven and earth are shaken to their foundations." 67 The closeted-ness of race thus becomes indispensable to the functioning of American "knowledge/power."

While much of Baldwin's work is illustrative of how racialized whiteness is naturalized through a similar process of "subsumption and exclusion" as heterosexuality, it is not the case that his writing merely realizes a racial counterpart to the homosexual closet. ${ }^{6}$ Throughout his career, Baldwin foregrounded the importance of recognizing that race and sexuality, though not reducible to one another, are closely entwined in the American imaginary. For instance, as alluded to above, in "History as Nightmare" (1947), a review of Chester Himes's 1947 novel Lonely Crusade, he refers to what he terms "the vast sexual implications of our racial heritage." ${ }^{99}$ Similarly, speaking in 1984, in what was one of his last published interviews, he asserts: "The sexual question and the racial question have always been entwined, you know. If Americans can mature on the level of racism, then they have to mature on the level of sexuality." ${ }^{70}$ Speaking about race in the United States, Baldwin understood, necessarily involves speaking about sexuality, and vice versa. More broadly, his oeuvre demonstrates that race and sexuality are imbricated within a larger matrix of power where whiteness, heterosexuality, and American identity are framed as coextensive epistemologies produced through competing discourses of ignorance and knowledge. To this end, his work provides an object lesson in how various forms of oppression intersect and interact.

The reciprocal relationship between whiteness, heterosexuality, and American identity that Baldwin identifies has prompted a number of scholars in the field of black queer studies to question the absence of race from Sedgwick's closet paradigm. Marlon B. Ross, for example, stresses the imperative of moving beyond the idea of the closet as a "raceless paradigm."71 In a similar vein, Maurice O. Wallace insists that "the singularly gay character of the closet no longer holds."72 Siobhan B. Somerville, meanwhile, unpacks the sexual dimensions of American racism to foreground the extent to which epistemologies of race and sexuality intersect in the American imaginary. In Queering the Color Line (2000), she makes a compelling case for there being a symbiotic relationship between the 1896 Plessy v. Ferguson ruling that formalized racial segregation, and contemporaneous anxieties around sexuality prompted by what Foucault famously describes as the invention of the homosexual as a distinct "species."73 Far from being a mere historical coincidence, Somerville argues how in the United States "the simultaneous efforts to shore up and bifurcate categories of race and sexuality in the late nineteenth century and early twentieth century were deeply entwined" with one another. ${ }^{74}$ She adds: "the formation of notions of heterosexuality and homosexuality emerged in the United States through (and not merely parallel to) a discourse 
saturated with assumptions about the racialization of bodies." ${ }^{\prime 5}$ In other words, sexuality was overdetermined by race, while race was always already freighted with connotations of queer sexuality. As a result, a paradigm of American-ness was institutionalized that placed blackness and queerness beyond the purview of what it meant to be an American.

Unsurprisingly, Baldwin's work offers fertile territory on which to pursue this relationship between race, sexuality, and national identity. His 1959 essay "Nobody Knows My Name" provides a particularly potent example of their commingling. The text, which recounts his first visit to the American South in 1958, proceeds within and against the social and political turmoil precipitated by the Civil Rights movement. Specifically, it considers the fallout from the Brown v. the Board of Education decision to desegregate public education in 1954 and the racial backlash it prompted among segregationists. Baldwin reads this cultural upheaval in the context of the South's closeted-ness concerning interracial sexuality and the attendant status anxiety that underpinned it. The lingering resentment toward the Supreme Court's decision among southern whites, Baldwin suggests, "has [...] nothing to do with education." Rather, "it has to do with political power and it has to do with sex."76 It is this relationship between sex, power, and race that Baldwin sets about unpacking in the essay. In doing so, he charts how the disavowal of one kind of "blood relationship" between black and white Americans, interracial sex and miscegenation, results in another kind: racially motivated lynching. ${ }^{77}$

The descriptions of lynching in "Nobody Knows My Name" foreground the way in which lynching is not only an act of racial violence, but also an act of sexual violence. Each of Baldwin's references to lynching emphasizes the image of a castrated, black, male body: "My mind was filled with the image of a black man [...] hanging from a tree, while white men watched him and cut his sex from him with a knife"; "How many times has the southern day come up to find that black man, sexless, hanging from a tree?"78 By focusing on the castration of his imagined victims, Baldwin frames lynching as an attempt to sublimate the desire for interracial sex on the part of white southern men. He references this desire when recounting the bleakly ironic observation of a light-skinned African American in Alabama to integration having "always worked very well in the South, after the sun goes down." 79 The spectre of miscegenation and the history of sexual violence that haunts this observation imperils the racialized basis on which hegemonic identity in the South is premised. ${ }^{80}$ Accordingly, lynching becomes another way of warding off the kind of "definitional crisis" discussed above. ${ }^{81}$ The "unspeakable longings" and "dreadful taboos" that overdetermine the history of interracial sexuality in the American South are reconstituted as a violence that is visited on the bodies, specifically the sexual organs, of black men. ${ }^{82}$

Projecting "unspeakable desires" and "dreadful taboos" onto the bodies of black men, before destroying them, preserves the closeted-ness of the South's Jim Crow era epistemology. The spectacle of the castrated black body becomes a way of restoring the South's racial dividing line and the asymmetrical power relations attendant to it. As Robyn Wiegman writes: 
Operating according to a logic of borders-racial, sexual, national, psychological, biological, as well as gendered-lynching figures its victims as the culturally abject, monstrosities of excess whose limp and lifeless bodies function as the specular assurance that the threat [to white hegemony] has not simply been averted, but thoroughly negated, dehumanized, and rendered incapable of return. ${ }^{83}$

In other words, by transmuting the "threat" of miscegenation into something abject, lynching enforces a representational domain in which blackness exists as a defiled otherness that must be kept separate from the white American "self." Lynching thus functions as a way of containing discourses relating to integration and miscegenation. As Wiegman continues, translating the threat to white supremacy into sexual terms in this way provided "a very powerful means through which not only black men, but the entire black community could be psychologically and physically contained." 84 In doing so, lynching maintains the unbridgeable "human separation" between white and black Americans that Baldwin refers to in "Stranger in the Village." 85

The link between repressed sexual desire and racial violence that Baldwin traces in "Nobody Knows My Name" demonstrates that the closet is not simply a vehicle for disciplining same-sex relations. Rather, the closeted sexuality of the American South described by Baldwin hinges on a fulcrum of race that is shown to be integral to the preservation of the region's existing social order. In other words, in the South, interracial desire is every bit as "queer," insofar as it threatens to destabilize the hierarchical, binary framework in which the region's identity is typically distributed, as same-sex desire. Maintaining the existing racialized social order, therefore, necessitates the closeted-ness of interracial desire. Accordingly, while Baldwin recounts being struck upon arriving in the South by the uncanny recognition that his "ancestors are both white and black," this knowledge is compelled to exist outside the representational domain. ${ }^{86}$ Despite being quite literally "written in the faces" of many of those he encounters, Baldwin demonstrates that it is only under the cover of darkness that the "dreadful taboos" and "unspeakable longings" accompanying interracial desire find some kind of articulation in the South. ${ }^{87}$ "What passions cannot be unleashed on a dark road in a southern night," he writes. "Desire can be acted here; over this fence, behind that tree, in the darkness, there; and no one will see, no one will ever know." 88 Interracial sex in the South, Baldwin suggests, must exist beyond the threshold of legibility, inhabiting the realm of non-speech and invisibility. In the dark of the southern night, he indicates, there exists another kind of love that "dare not speak its name."

If "Nobody Knows My Name" demonstrates the extent to which blackness is overdetermined with connotations of queer sexuality, then Baldwin's third novel, Another Country, illustrates that the reverse also holds. This idea is distilled most clearly when Baldwin describes Eric, a white actor from a wealthy Alabama family, reminiscing about his first sexual encounter, a liaison with an African American named LeRoy, as a teenager. Mirroring the world depicted 
in "Nobody Knows My Name," the relationship between Eric and LeRoy is set against the closeted-ness of the South's racialized psychosexual neuroses. The language Baldwin uses to describe the encounter foregrounds the difficulty of interpreting and representing their desire for one another in a society where the only terms available to describe it render it abject. Setting the scene, Baldwin notes how "the silence of the South hung heavy." 89 He proceeds to detail the interpretive difficulties posed by a rich white boy associating with a poor black boy in such a climate, writing:

[T]heir friendship, their effort to continue an impossible connection, was beginning to be a burden on them both. It would have been simpler-perhaps-if LeRoy had worked for Eric's family. Then all would have been permitted, would have been covered by the assumption of Eric's responsibility for his coloured boy. But, as things were, it was suspect, it was indecent. ${ }^{90}$

The only intelligible context for their relationship, Baldwin suggests, is an economic one characterized by asymmetrical power relations.

The absence of a field of knowledge capable of legitimizing Eric and LeRoy's relationship within the existing power structure of the South results in it having to play out in the realm of non-speech. Their mutual attraction for one another is referred to as having been "something unspoken between them, something unspeakable," while Eric recalls "aching and yearning for the act," yet unable to find a language capable of articulating his desire accurately: "It had yet to reach the threshold of his imagination; and it had no name, no name for him anyway, though for other people, so he had heard it, it had dreadful names." ${ }^{11}$ Baldwin's description here reveals the power of a closeted-ness that is formulated along multiple, intersecting axes. Eric and LeRoy's relationship is one that transgresses fault lines of race, gender, sexuality, and class. By blurring the distinction between these categories in this way, Baldwin reveals them to be contingent terms. In doing so, he helps "debunk" what Roderick A. Ferguson characterizes as a counterproductive tendency in American cultural discourse that suggests that "race, class, gender, and sexuality are discrete formations, apparently insulated from one another." 92

The mutually constitutive relationship between the identity formations described by Ferguson is underlined by LeRoy, when he warns Eric of the physical danger they will both face if their relationship is discovered. "You better get out of this town," he states. "Declare, they going to lynch you before they get around to me." 93 In LeRoy's formulation, Eric's queerness divests him of his whiteness, leaving him susceptible to the same obscene, supplementary violence of lynching that is used to preserve white hegemony. Just as the black body in a segregated society is always already queer, so the queer body is framed here as being always already racialized as non-white and thus compelled to forfeit the cultural and economic privileges that accompany whiteness. The overriding effect is to underscore the reciprocal relationship between whiteness, heterosexuality, and, indeed, class 
privilege in the American imaginary. Baldwin demonstrates how, in their dominant form, each of these categories derives its power from a closeted otherness that may contain the disavowed elements of various other identity formations. Within such a framework, whiteness is not merely a racial category, but also a sexual and economic one, and, by the same token, heteronormativity and wealth are racialized as being the domain of whiteness.

Accordingly, it seems curiously schematic for Sedgwick to insist on the "historical gay specificity" of the epistemology she traces. ${ }^{94}$ Given the extent to which racial difference has been constitutive of both American history and that of Western modernity more broadly, the almost total of absence of race from her analysis is particularly problematic. By denying its relevance, Sedgwick appears to rehearse what Matt Brim has described as an occasional tendency in queer theory to "recenter whiteness." ${ }^{95}$ In doing so, she perpetuates the very "compulsions" the closet inscribes and she herself cautions against. ${ }^{96}$ Overlooking the extent to which the experience of modernity is racialized, she effectively elides the historical identities of non-white populations. Reading Sedgwick through Baldwin, however, demonstrates how introducing a racial component into her analysis may expand its conceptual limits without detracting from its efficacy for comprehending the ways in which heteronormativity is naturalized. As Dwight A. McBride notes, Baldwin "reminds us that whenever we are speaking of race, we are always already speaking about gender, sexuality, and class." ${ }^{\text {"97 }}$ Equally, to speak about sexuality necessarily involves speaking about race, gender, and class. Placing Baldwin and Sedgwick in dialogue with one another, therefore, opens up new interpretive possibilities that expand our understanding of how ignorance and knowledge collude in the production of hegemonic power relations.

The importance of this kind of intersectional critique has become particularly pronounced as we try to navigate the seeming incomprehensibility of our own troubled age. In an era of "fake news" and "alternative facts," where building walls and implementing travel bans are used to restore a putative "greatness" predicated on legible boundaries between the American "self" and the "other," Baldwin's warning that "ignorance allied with power is the most ferocious enemy justice can have" resounds with renewed urgency. ${ }^{98}$ Yet, while the enduring relevance of his words is undoubtedly dispiriting, Baldwin himself recognized that the only way to counter this ignorance is through communion across boundaries of race, gender, and sexuality. Repudiating those "airless, labelled cells, which isolate us from each other and separate us from ourselves," he was steadfast in his insistence that "each of us, helplessly and forever, contains the other-male in female, female in male, white in black and black in white." ${ }^{99}$ As he puts it in his famous conclusion to The Fire Next Time:

If we-and now I mean the relatively conscious whites and the relatively conscious blacks, who must, like lovers, insist on, or create, the consciousness of the others-do not falter in our duty now, we may be able, handful that we are, to end the racial nightmare, and achieve our country, and change the history of the world. ${ }^{100}$ 
With this image of love and knowledge communicated across fault lines of race and sexuality, Baldwin explodes the closeted-ness of American power. In doing so, he outlines the basis for a new collective consciousness that makes the hitherto "unspeakable" articulate. As we confront the perilous path before us, we- "handful that we are"-would do well to heed this advice. Doing so may just prevent the fires of our time from consuming us all.

\section{Notes}

1 “Malcolm X-Debate With James Baldwin", 5 September 1963, YouTube video, www. youtube.com/watch?v=-JIp9_IIV3s (accessed 15 May 2016).

2 Ibid.

3 Ibid.

4 Ibid.

5 Ibid.

6 Ibid.

7 James Baldwin, “The Fire Next Time” (1963), in The Price of the Ticket: Collected Nonfiction, 1948-1985 (New York, St. Martin's/Marek, 1985), pp. 333-80 (p. 344).

8 James Baldwin, "Many Thousands Gone" (1951), in The Price of the Ticket, pp. 65-78 (p. 68).

9 James Baldwin, "Nobody Knows My Name" (1959), in The Price of the Ticket, pp. 183-93 (p. 189).

10 Oscar Wilde, The Wit and Humour of Oscar Wilde (New York, Dover Publications, 1959), p. 240; James Baldwin, Another Country (1962) (London, Penguin, 2001), p. 202.

11 "Malcolm X-Debate With James Baldwin."

12 Eve Kosofsky Sedgwick, Epistemology of the Closet (1990) (Berkeley, CA, University of California Press, 2008), p. 71.

13 James Baldwin, Giovanni's Room (1956) (London, Penguin, 2001), p. 135. For more on Giovanni's Room and the homosexual closet, see Phillip Auger, Native Sons in No Man's Land: Re-writing Afro-American Manhood in the Novels of Baldwin, Walker, Wideman, and Gaines (New York, Garland Publishing, 2000), pp. 15-28.

14 Sedgwick, Epistemology of the Closet, p. 3.

15 Auger, Native Sons, p. 21.

16 Sedgwick, Epistemology of the Closet, p. 10.

17 Ibid., p. 4.

18 Ibid., pp. 72, 73.

19 Ibid., p. 72.

20 Ibid., pp. 72-3.

21 Ibid., p. 72.

22 James Baldwin, "History as Nightmare" (1947), in Collected Essays, ed. Toni Morrison (New York, Library of America, 1998), pp. 579-81 (p. 579); Marlon B. Ross, "Beyond the Closet as a Raceless Paradigm," in E. Patrick Johnson and Mae G. Henderson (eds.), Black Queer Studies: A Critical Anthology (Durham, N.C., Duke University Press, 2005), p. 162.

23 Alan Nadel, Containment Culture: American Narratives, Postmodernism, and the Atomic Age (Durham, N.C., Duke University Press, 1995), pp. 29, 34. 
24 For more on the impact of Cold War "containment" on American culture, see David Ryan, "Mapping Containment: The Cultural Construction of the Cold War," in Douglas Field (ed.), American Cold War Culture (Edinburgh, Edinburgh University Press, 2005), pp. 50-68.

25 Sedgwick, Epistemology of the Closet, p. 72. For more on the "lavender scare," see David K. Johnson, The Lavender Scare: The Cold War Persecution of Gays and Lesbians in the Federal Government (Chicago, University of Chicago Press, 2004).

26 Sedgwick, Epistemology of the Closet, p. 29.

27 James Baldwin, "Stranger in the Village" (1953), in The Price of the Ticket, pp. 79-90 (p. 89).

28 Ibid.

29 James Baldwin, "In Search of a Majority" (1960), in The Price of the Ticket, pp. 229-35 (p. 232).

30 Baldwin, "Stranger in the Village," p. 89.

31 Mary L. Dudziak, Cold War Civil Rights: Race and the Image of American Democracy (Princeton, N.J., Princeton University Press, 2011 [2002]), p. 111; Reynold Humphries, Hollywood's Blacklists: A Political and Cultural History (Oxford, Oxford University Press, 2008), p. 12.

32 Baldwin, "Stranger in the Village," p. 89.

33 Baldwin, "The Fire Next Time," p. 344.

34 Ibid., p. 362.

35 Ibid., p. 336.

36 Nadel, Containment Culture, p. 29.

37 Baldwin, "The Fire Next Time," p. 376.

38 Ibid., p. 362; Sedgwick, Epistemology of the Closet, p. 10.

39 Baldwin, "The Fire Next Time," p. 344; Sedgwick, Epistemology of the Closet, p. 21.

40 Sedgwick, Epistemology of the Closet, p. 4.

41 Ibid., p. 8.

42 Michel Foucault, Discipline and Punish: The Birth of the Prison, trans. Alan Sheridan (New York, Vintage Books, 1979), p. 27.

43 Ibid.

44 Baldwin, "The Fire Next Time," p. 362.

45 Sedgwick, Epistemology of the Closet, p. 4.

46 Baldwin, "The Fire Next Time," p. 344.

47 Sedgwick, Epistemology of the Closet, p. 21; Baldwin, "The Fire Next Time," p. 344.

48 Baldwin, "The Fire Next Time," p. 377.

49 Baldwin, "Many Thousands Gone," p. 77.

50 Grace Tiffany, "Eden and the New World in Shakespeare's The Tempest," in Viorica Patea and María Eugenia Díaz (eds.), Critical Essays on the Myth of the American Adam (Salamanca, Ediciones Universidad de Salamanca, 2001), p. 45.

51 John Winthrop, "A Model of Christian Charity" (1630), in Richard S. Dunn and Laetitia Yeandle (eds.), The Journal of John Winthrop: Abridged Edition (Cambridge, MA, Harvard University Press, 1996), p. 10.

52 H. W. Brands, The Devil We Knew: Americans and the Cold War (Oxford, Oxford University Press, 1994), pp. 38-9.

53 Ibid. 
54 See, for example, Richard Keenan, "American Adam," in Steven R. Serafin and Alfred Bendixen (eds.), The Continuum Encyclopedia of American Literature (New York, Continuum, 2003), pp. 37-8, and Jonathan Mitchell, Revisions of the American Adam: Innocence, Identity and Masculinity in Twentieth Century America (New York, Continuum, 2011).

55 David Leeming, "An Interview with James Baldwin on Henry James," The Henry James Review, 8:1 (1986), p. 54.

56 George Shulman, "Baldwin, Prophecy, and Politics," in Cora Kaplan and Bill Schwarz (eds.), James Baldwin: America and Beyond (Ann Arbor, MI, University of Michigan Press, 2011), p. 108.

57 Baldwin, “The Fire Next Time," p. 334.

58 Shulman, "Baldwin, Prophecy, and Politics," p. 108; Baldwin, quoted in Leeming, "An Interview with James Baldwin on Henry James," p. 54.

59 Baldwin, "The Fire Next Time," p. 334.

60 For more on the idea of ignorance as power, see Eve Kosofsky Sedgwick, "Privilege of Unknowing: Diderot's The Nun" (1988), in Tendencies (Durham, N.C., Duke University Press, 1993), pp. 23-51.

61 Sedgwick, Epistemology of the Closet, p. 14.

62 Lawrie Balfour, "Finding the Words: Baldwin, Race Consciousness and Democratic Theory," in Dwight A. McBride (ed.), James Baldwin Now (New York, New York University Press, 1999), p. 77. For more on the idea of innocence as ignorance, see Kelvin Beliele, "The Prophetic Burden: James Baldwin as a Latter-Day Jeremiah," in Emily Griesinger and Mark Eaton (eds.), The Gift of Story: Narrating Hope in a Postmodern World (Waco, TX, Baylor University Press, 2006), p. 203.

63 Baldwin, “The Fire Next Time," p. 334.

64 Sedgwick, Epistemology of the Closet, p. 12.

65 Baldwin, “The Fire Next Time," pp. 334, 362.

66 Sedgwick, Epistemology of the Closet, p. 11; Baldwin, “The Fire Next Time," p. 336.

67 Baldwin, "The Fire Next Time," p. 336.

68 Sedgwick, Epistemology of the Closet, p. 10.

69 Baldwin, "History as Nightmare," p. 579.

70 Richard Goldstein, "Go the Way Your Blood Beats: An Interview with James Baldwin" (1984), in Quincy Troupe (ed.), James Baldwin (New York, Simon \& Schuster, 1989), p. 183.

71 Ross, "Beyond the Closet," p. 162.

72 Maurice O. Wallace, Constructing the Black Masculine: Identity and Ideality in African-American Men's Literature and Culture (Durham, N.C., Duke University Press, 2002), p. 115.

73 Michel Foucault, The History of Sexuality, Volume 1: An Introduction (1976), trans. Robert Hurley (London, Penguin, 1990), p. 43.

74 Siobhan B. Somerville, Queering the Color Line: Race and the Invention of Homosexuality in American Culture (Durham, N.C., Duke University Press, 2000), pp. 3, 4 .

75 Ibid.

76 Baldwin, "Nobody Knows My Name," p. 185.

77 In "Many Thousands Gone," Baldwin writes that the relationship between black and white Americans "is not simply the relationship of oppressed to oppressor, of 
master to slave, nor is it motivated merely by hatred; it is also, literally and morally, a blood relationship" (emphasis in original). Baldwin, "Many Thousands Gone," pp. 76-7.

78 Baldwin, "Nobody Knows My Name," p. 188.

79 Ibid., p. 192.

80 Ibid.

81 Sedgwick, Epistemology of the Closet, p. 12.

82 Baldwin, "Nobody Knows My Name," p. 189.

83 Robyn Wiegman, “The Anatomy of Lynching," Journal of the History of Sexuality, 3:3 (1993), pp. 445-6.

84 Ibid., p. 456.

85 Baldwin, "Stranger in the Village," p. 89.

86 Baldwin "Nobody Knows My Name," p. 183.

87 Ibid., p. 188.

88 Ibid., p. 189.

89 Baldwin, Another Country, p. 200 (emphasis added).

90 Ibid.

91 Ibid., p. 202.

92 Roderick A. Ferguson, Aberrations in Black: Toward a Queer of Color Critique (Minneapolis, MN, University of Minnesota Press, 2004), p. 4.

93 Baldwin, Another Country, p. 204.

94 Sedgwick, Epistemology of the Closet, p. 72.

95 Matt Brim, James Baldwin and the Queer Imagination (Ann Arbor, MI, University of Michigan Press, 2014), p. 20.

96 Sedgwick, Epistemology of the Closet, p. 73.

97 Dwight A. McBride, "Straight Black Studies: On African-American Studies, James Baldwin, and Black Queer Studies," in Johnson and Henderson (eds.), Black Queer Studies, p. 87.

98 James Baldwin, No Name in the Street (New York: Vintage, 1972), p. 149.

99 James Baldwin, "Preservation of Innocence" (1949), in Morrison (ed.), James Baldwin: Collected Essays, pp. 594-600 (p. 600); James Baldwin, "Here Be Dragons" (1985), in The Price of the Ticket, pp. 677-90 (pp. 678, 690).

100 Baldwin, “The Fire Next Time," p. 379.

\section{Works Cited}

Auger, Phillip, Native Sons in No Man's Land: Re-writing Afro-American Manhood in the Novels of Baldwin, Walker, Wideman, and Gaines (New York, Garland Publishing, 2000).

Baldwin, James, Another Country (1962) (London, Penguin, 2001).

- Giovanni's Room (1956) (London, Penguin, 2001).

James Baldwin: Collected Essays, ed. Toni Morrison (New York, Library of America, 1998).

No Name in the Street (New York, Vintage, 1972).

- The Price of the Ticket: Collected Nonfiction, 1948-1985 (New York, St. Martin's/ Marek, 1985).

Balfour, Lawrie, "Finding the Words: Baldwin, Race Consciousness and Democratic 
Theory," in Dwight A. McBride (ed.), James Baldwin Now (New York, New York University Press, 1999), pp. 75-99.

Beliele, Kelvin, “The Prophetic Burden: James Baldwin as a Latter-Day Jeremiah," in Emily Griesinger and Mark Eaton (eds.), The Gift of Story: Narrating Hope in a Postmodern World (Waco, TX, Baylor University Press, 2006), pp. 187-206.

Brands, H. W., The Devil We Knew: Americans and the Cold War (Oxford, Oxford University Press, 1994).

Brim, Matt, James Baldwin and the Queer Imagination (Ann Arbor, MI, University of Michigan Press, 2014).

Dudziak, Mary L., Cold War Civil Rights: Race and the Image of American Democracy (Princeton, N.J., Princeton University Press, 2011 [2002]).

Ferguson, Roderick A., Aberrations in Black: Toward a Queer of Color Critique (Minneapolis, MN, University of Minnesota Press, 2004).

Foucault, Michel, Discipline and Punish: The Birth of the Prison, trans. Alan Sheridan (New York, Vintage Books, 1979).

The History of Sexuality, Volume 1: An Introduction (1976), trans. Robert Hurley (London, Penguin, 1990).

Goldstein, Richard, "Go the Way Your Blood Beats: An Interview with James Baldwin" (1984), in Quincy Troupe (ed.), James Baldwin (New York, Simon \& Schuster, 1989), pp. 173-85.

Humphries, Reynold, Hollywood's Blacklists: A Political and Cultural History (Oxford, Oxford University Press, 2008).

Johnson, David K., The Lavender Scare: The Cold War Persecution of Gays and Lesbians in the Federal Government (Chicago, University of Chicago Press, 2004).

Keenan, Richard, "American Adam," in Steven R. Serafin and Alfred Bendixen (eds.), The Continuum Encyclopedia of American Literature (New York, Continuum, 2003), pp. 37-8.

Leeming, David Adams, "An Interview with James Baldwin on Henry James," The Henry James Review, 8:1 (1986), pp. 47-56.

"Malcolm X-Debate With James Baldwin" (1963), 5 September 1963, www.youtube.com/ watch?v=-JIp9_IIV3s (accessed 15 May 2016).

McBride, Dwight A., "Straight Black Studies: On African-American Studies, James Baldwin, and Black Queer Studies," in E. Patrick Johnson and Mae G. Henderson (eds.), Black Queer Studies: A Critical Anthology (Durham, N.C., Duke University Press, 2005), pp. 68-90.

Mitchell, Jonathan, Revisions of the American Adam: Innocence, Identity and Masculinity in Twentieth Century America (New York, Continuum, 2011).

Nadel, Alan, Containment Culture: American Narratives, Postmodernism, and the Atomic Age (Durham, N.C., Duke University Press, 1995).

Ross, Marlon B., "Beyond the Closet as a Raceless Paradigm," in E. Patrick Johnson and Mae G. Henderson (eds.), Black Queer Studies: A Critical Anthology (Durham, N.C., Duke University Press, 2005), pp. 161-89.

Ryan, David, "Mapping Containment: The Cultural Construction of the Cold War," in Douglas Field (ed.), American Cold War Culture (Edinburgh, Edinburgh University Press, 2005), pp. 50-68.

Sedgwick, Eve Kosofsky, Epistemology of the Closet (1990) (Berkeley, CA, University of California Press, 2008). 
Tendencies (Durham, N.C., Duke University Press, 1993).

Shulman, George, "Baldwin, Prophecy, and Politics," in Cora Kaplan and Bill Schwarz (eds.), James Baldwin: America and Beyond (Ann Arbor, MI, University of Michigan Press, 2011), pp. 106-25.

Somerville, Siobhan B., Queering the Color Line: Race and the Invention of Homosexuality in American Culture (Durham, N.C., Duke University Press, 2000).

Tiffany, Grace, "Eden and the New World in Shakespeare's The Tempest," in Viorica Patea and María Eugenia Díaz (eds.), Critical Essays on the Myth of the American Adam (Salamanca, Ediciones Universidad de Salamanca, 2001), pp. 45-52.

Wallace, Maurice O., Constructing the Black Masculine: Identity and Ideality in AfricanAmerican Men's Literature and Culture (Durham, N.C., Duke University Press, 2002).

Wiegman, Robyn, "The Anatomy of Lynching," Journal of the History of Sexuality, 3:3 (1993), pp. 445-67.

Wilde, Oscar, The Wit and Humour of Oscar Wilde (New York, Dover Publications, 1959). Winthrop, John, "A Model of Christian Charity" (1630), in Richard S. Dunn and Laetitia Yeandle (eds.), The Journal of John Winthrop: Abridged Edition (Cambridge, MA, Harvard University Press, 1996), pp. 1-12.

\section{Contributor's Biography}

David C. Jones received his Ph.D. from the University of Manchester in 2015. His thesis examines the work of Ralph Ellison, Richard Wright, James Baldwin, and Lorraine Hansberry in relation to the Cold War and discourses of black internationalism. He currently works at Edge Hill University, having previously taught English Literature and American Studies at Newcastle University and the University of Manchester. 